\title{
The Effect of Family Empowerment in Nursing Implementation Toward Self-Efficacy among Patients with Diabetes Mellitus
}

Indonesian Nursing Journal of Education and Clinic (INJEC)

|4|-|46

Volume 5, Issue 2, December 2020

DOI: 10.24990/injec.v5i2.303

injec.aipni-ainec.org/index.php/INJEC/index

Received : 2020-06-08

Accepted : 2020-07-23

The Association of Indonesian Nurse

Education Center (AINEC)

\author{
Fadil Al Mahdi' ${ }^{1}$, Candra Kusuma Negara' ${ }^{(1 D}$, Abd Basid'
}

\begin{abstract}
Introduction: : Diabetes mellitus is a condition where the body cannot produce the insulin hormone as needed so that there is an excess of normal blood sugar levels. Giving family empowerment in clients with gangrene foot diabetes should be done comprehensively using the nursing process. Interventions that can be done are family empowerment to motivate and improve the self-efficacy of patients with diabetes mellitus. The purpose of this study was to determine the effect self-efficacy before and after the implementation of family empowerment in nursing in patients with diabetes mellitus.

Methods: Pre-experiment research with pretest and posttest study design without control group. Forty respondents who met the inclusion criteria were then tested using purposive sampling. The instrument in this study used a self-efficacy questionnaire. The dependent variable of this study is selfefficacy, while the independent variable is family empowerment using the paired sample t-test parametric analysis method.

Results: Based on what was answered by the respondents there was a significant influence which showed difference after the posttest. The results obtained values: $\alpha=0.05$ which calculated the results of $p=0.00(p<0.05)$. This means that, after a posttest, there was a decrease in motivation and selfefficacy.

Conclusion: Researchers concluded that there is an effect of family empowerment on patients with diabetes mellitus. The implication of this study is that the role of family is very important in healing patients.
\end{abstract}

\section{Keywords}

diabetes; family empowerment; self-efficacy

\section{INTRODUCTION}

Diabetes mellitus is a condition where the body cannot produce the insulin hormone as needed or the body cannot make optimal use of the insulin produced, resulting in a surge or excess blood sugar levels that exceed normal. Diabetes mellitus can also occur because the hormone insulin produced by the body cannot work properly (Fitriana et al., 2016).

Diabetes mellitus and its complications are still a health problem in the world and are a cause of death. In fact, the prevalence of

\footnotetext{
' High School of Health Science Cahaya Bangsa, Banjarmasin

Corresponding Author:

Fadil AI Mahdi, High School og Health Science Banjarmasin, Indonesia

Jl. A. Yani No.KM 17, Malintang Baru, Kec. Gambut, Banjar, Kalimantan Selatan 70122, Indonesia

Email: Fadhil88@yahoo.com
} 
diabetes mellitus has reached epidemic rate proportions globally and is increasing continuously. In 2003, the prevalence of diabetics was 194 million and it is estimated that, by 2025, the figure will reach up to 333 million in developing countries and those with low economics (Hutama, 2016). The goals of diabetes mellitus treatment are to reduce the risk of microvascular and macrovascular complications, improve symptoms of complications, reduce the number of cases of death, and improve the quality of life of people with diabetes mellitus. The risk of complications resulting from the management of medication and diet, as well as efforts to prevent complications of diabetes mellitus, can potentially affect the quality of life for sufferers. Health professionals should pay more attention to the quality of life of people with diabetes mellitus because it can be a reference to the success of an intervention or therapy (Astuti \& Neneng, 20I4).

The application of family empowerment nursing interventions to improve coping of family and patient with type 2 diabetes mellitus is still very rarely done by nurses and little research is done, this is because many researchers look more at the aspect of family empowerment in terms of increasing knowledge and attitudes alone, and does not extend to the coping ability of the family. For families with diabetes mellitus, it is not only the knowledge and attitude aspects that are the goal of the intervention, but the level of ability to live a healthy and productive life with family members having type 2 diabetes mellitus.

\section{MATERIALS AND METHODS}

The method used in this study is the preexperiment with a pretest and posttest research design without a control group because all patients and families have received family empowerment from the hospital so that there are no families and patients who lack these actions. Here the researcher empowers back to the family concerning therapeutic treatment, diet, diet, activity patterns, and others. The population of this study is all diabetic patients who were hospitalized in the last three (3) months amounting to 60 people (hospital data per I May - I July 2019).In this study, researchers wanted to find the effect of Family Empowerment in Nursing Influence on Self-Efficacy in Diabetes Mellitus Patients in Banjarmasin, with statistical tests using the SPSS For Windows independent t-test. The research location chosen by the researcher is in the Diabetic Foot Room of Hospital Banjarmasin, Banjarmasin, and the length of the study is January 2020 to September 2020. In this study, the sampling technique used was purposive sampling, namely all patients suffering from diabetes mellitus with diabetic ulcer in the Diabetic Foot Poly Room, willing to be a respondent, and can communicate well.

Patients having received family empowerment from the previous hospital, at the next visit were given a questionnaire regarding self-efficacy. Data processing was done with a computerized system, namely: editing, coding / scoring, processing, and tabulation. The research instrument used in this study was the provision of a questionnaire regarding the self-efficacy adopted from Doya (2017) and validity and reliability tests have been conducted. Checklist model questionnaire consisted of 18 questions with three levels, $I=$ Not Able, 2 = Poor, $3=$ Able. Good category was when a score of 42-54, Sufficient 30-4I, and Less 18-29. This research has been tested by the Ethics Commission of Ulin Hospital with No.320 / IIReg Research / RSUDU / 20.

Table I Characteristics by Age of Respondents in the Banjarmasin Region in South Kalimantan

\begin{tabular}{cccc}
\hline No. & Gender & $\mathbf{n}$ & $\mathbf{( \% )}$ \\
\hline 1. & Male & 17 & 30 \\
2. & Female & 23 & 70 \\
\hline & & 40 & 100 \\
\hline
\end{tabular}

Table 2 Bivariate analysis self-efficacy

\begin{tabular}{ccccccc}
\hline No & Self-efficacy & Mean & Max & Min & Sd & p \\
\hline 1. & Before & 40.20 & 3 & 1 & 0.616 & 0.000 \\
2. & After & 42.60 & 3 & 2 & 0.681 & \\
\hline
\end{tabular}




\section{RESULTS}

Based on Table I, it can be seen that respondents aged 30-44 years are 10 people (25\%), aged $45-59$ years are 16 people $(40 \%)$, and those aged $60-74$ years are 14 people (35\%).

Paired sample t-test analysis based on Table 2 obtained data with $p=0.00(p<0.05)$, which means that $\mathrm{HO}$ is rejected, there is a significant influence that leads to difference posttest, while the self-efficacy variable with the results of $p=0.00(p<0.05)$ means that $\mathrm{HO}$ is rejected and there is a significant effect showing difference posttest.

\section{DISCUSSIONS}

Researchers gave family empowerment in nursing patients who suffer from diabetes mellitus in the form of family and went to the patient's house to make a visit. On the first visit the researchers gave a questionnaire to patients with self-efficacy diabetes and gave family empowerment in the form of counseling for six (6) days and the data obtained on that first day were that the patient feels proud of the support of the family and, when given a questionnaire, answered "family relationship with me when sick is very helpful in the healing process".

However, at all stages of the lifecycle, family social support makes the family able to function with a variety of intelligence and reasons. As a result, this improves health and family adaptation. Wills and Friedman (cited in Ardian, 20I3) conclude that both buffering effects (family social support withstand negative effects of stress on health) and main effects (family social support directly influencing health effects) were also found to be actually buffering effects and welfare may function together (Susanti \& Sulistyartini, 2013).

The questionnaire asking "family relationship with me when sick is very helpful in the healing process" showed results 100\% (20 respondents) said agreed. Family support when sick in the healing process is all forms of positive behavior and attitudes given by the family to one of the sick family members, namely family members who experience health problems. (Friedman, 2010). However, not all
DM clients have good family support (Amelia \& Nurchayati, 20I4).

Based on Table 2, it shows that, after being completing the questionnaire, based on what was filled out by the respondents, there was a significant effect which was toward negative or difference after the posttest and the results obtained $p=0.00(p<0.05)$.

After being given the self-efficacy (postest) on the last day, which was the 6th day after the research, the patient filled out the questionnaire (postest), and the data obtained on the 6th day of visit, based on Table 2, shows that the average efficacy after being given counseling (postest) is 42.60. And after the self-efficacy post was administered, the questionnaire "I am sure a lot of physical activity" results showed 60\% (12 respondents) said they were less able; here there was a decrease when self-efficacy was carried out due to complications that often occur if it is uncontrolled and not handled properly, with the emergence of various comorbidities in various organs of the body, such as the eyes, kidneys, heart, leg veins and nervous system. For that we need good cooperation between patients, families, the community and also health workers in handling and managing diabetics (Santoso \& Singgih, 2010).

Physical exercise in people with DM has a very important role in controlling blood sugar levels, where, when doing physical exercise, there is an increase in the use of glucose by active muscles so that it can directly cause a decrease in blood glucose. In addition, physical exercise can reduce weight, improve cardiovascular function and respiration, reduce LDL and increase HDL so as to prevent coronary heart disease if done correctly and regularly. Prompts for sports or physical exercise were actually not new before the discovery of insulin in 1921, but, at that time, it was not clear the limits of physical exercise that had to be done, such as the type of exercise, dosage, frequency or intensity of exercise (Sido \& Soegondo, 1995). People with diabetes mellitus should do it (Indriyani \& Supriyanto, 2007).

When self-efficacy posttest was given, the questionnaire "I find it difficult to check the type of food when traveling" showed results of $90 \%$ (I 8 respondents) with the need for foods made from whole grains or complex 
carbohydrates, such as brown rice, baked sweet potatoes, oatmeal, bread, meat lean or skinless chicken, vegetables that are processed by boiling, steaming, roasting or raw consumption. Vegetables that are good in consumption for diabetics include broccoli and spinach, fresh fruits, nuts, low-fat dairy products, such as yogurt and eggs and various types of fish, such as tuna, salmon, sardines and mackerel. However, avoid fish with high cadres, such as tuna (Adman \& Monica, 20I7).

After the self-efficacy posttest was given, the questionnaire "I choose the best food for my health" showed results of $90 \%$ (18 respondents), which means an increase after self-efficacy posttest. The best types of food for people with diabetes mellitus are: vegetables, such as broccoli, spinach, asparagus, cauliflower, eggplant, pumpkin; fruits, such as oranges, grapes, kiwi, tomatoes, bananas, apples, strawberries; grains such as brown rice, wheat paste, whole wheat bread, oat mil, millet, amaranth; meat and fish, such as lean meat, skinless chicken, fish; tofu, egg, low-fat milk; and drinks such as mineral water, unsweetened coffee, unsweetened tea, and fruit juice without fruit (Patria, 2018).

Based on the research, Table 4 shows that, after giving self-efficacy to the family, after completing the questionnaire, based on what was filled in by the respondents, there was significant influence, negative or decreased, after the posttest and the results obtained $p=$ 0.00 ( $p<0.05)$. Thus, this questionnaire cannot be applied in Banjarmasin, especially it cannot be applied in the Diabetic Foot Poly Room of Hospital, Banjarmasin.

The characteristics of respondents had nothing to do with self-efficacy except for work ( $p$ value $=0,000 ; \alpha=0.05)$ and education ( $P$ value $=0.049 ; \alpha=0.05)$. There is a relationship between family support and self-efficacy ( $P$ value $=0.045 ; \alpha=0.05)$, between depression and self-efficacy ( $p$ value $0.022 ; \alpha: 0.05$ ), and motivation is related to self-efficacy ( $P$ value $0,000 ; \alpha: 0.05)$. Respondents who have good motivation have 4,315 times the opportunity to have good self-efficacy compared to respondents who have poor motivation after being controlled by work, education, family support, and depression (OR 95\% Cl: 0.0826.874) (Hernilawati, 20I3).

Self-efficacy is an individual's beliefs about themselves. "Self-efficacy is the belief of the extent of individual estimates his ability in executing a task or action required to achieve." Efficacy is a belief in the extent to which an individual estimates his ability to carry out the task or action needed to achieve it. Self-efficacy is a person's confidence that he is able to complete or carry out academic tasks. High self-efficacy will believe that they are able to do something to achieve success (Adman \& Monica, 2017).

Self-efficacy is an individual's beliefs about personal ability to work performance. Selfefficacy is the patient's confidence in his ability to perform various diabetes self-management behaviors. Self-efficacy is the basis for increasing the effectiveness of diabetes education because it focuses on behavioral change. Efficacy of a strong predictor of diabetes self-management. Someone who lives with diabetes who has a higher level of selfefficacy will participate in better diabetes selfmanagement behavior (Andra \& Putri, 20I3). Diabetics will experience psychological and psychosomatic effects, insecurity and lack of confidence arises as a result of the complications of diabetes (Negara, 2017).

Self-efficacy is a key idea from social cognitive theory developed by Albert Bandura. Self-efficacy affects how a person thinks, feels, motivates himself and acts. Self-efficacy drives the process of self-control to maintain the behavior needed in managing self-care in DM patients. According to Bandura (1994), selfefficacy can be formed and developed through four processes, namely cognitive, motivational, affective and selection. According to the International Council of Nurses (ICN, 20I0), one of the chronic disease care models developed today is the Chronic Care Model (CCM), which is a patient care model that focuses on the interaction of active and informed patients with a health team that is proactive and ready to serve. This means a relationship of patients who are motivated and knowledgeable and are confident in making decisions about their health with a team that is able to provide information about the foot care, and motivation and resources of good quality care are needed (Purwanti, 20I4).

Self-efficacy is one's belief in the ability to organize in carrying out a series of actions needed to achieve the desired goals. Selfefficacy is a subjective picture of self-ability that is fragmental, that is, each individual has 
different self-efficacy in different situations (Muhibuddin et al., 2016).

\section{Family Empowerment in Nursing}

The implementation of family empowerment nursing interventions to improve coping of families with type 2 diabetes mellitus is still very rarely performed by nurses and little research is done; this is because many researchers look more at the aspect of family empowerment on the side of increasing knowledge and attitudes alone, and do not extend to the coping ability of the family. For families with diabetes mellitus it is not only the knowledge and attitude aspects that are the goal of the intervention but, up to the level of ability to live a healthy and productive life with family members having type 2 diabetes mellitus (Ardian, 2013).

Family empowerment is a form of positive behavior and attitude given by the family to one family member who is sick, namely family members who experience health problems (Amelia \& Nurchayati, 20I4).

The family needs to provide information in order to increase the patient's knowledge about controlling his illness. This requires the use a patient-centered approach by identifying many barriers to blood sugar control, such as the ignorance of doctors from patients that they fear, belief, hope and limitations of the biomedical approach to patients who are less adherent. Family members are very involved in providing intervention in type 2 DM patients in providing emotional and psychological support, helping develop knowledge, attitudes and behavior of healthy sufferers, and promoting independent diabetes management (Muhibuddin, 2016).

Diabetes mellitus is a hereditary disease that is difficult to cure. From year to year diabetics in Indonesia are increasing. Diabetes mellitus is a chronic disease that causes multisystem disorders and has the characteristics of hyperglycemia caused by insulin deficiency or inadequate insulin action (Hidayat et al., 20I4).

A study conducted by Negara (2018) found that the role of the family at home had a significant influence on changes in the health conditions of diabetic patients. This shows the role of the family, such as support and motivation, is very influential in the healing of diabetic patients. Research results conducted by Negara (2018) show that discharge planning is very influential on the progress of subsequent health conditions, knowledge of therapy, interventions, and care by families is very potential in healing patients.

Diabetes Mellitus is a condition where the body cannot produce the insulin hormone as needed or the body cannot make optimal use of the insulin produced, resulting in a surge or excess blood sugar levels that exceed normal. Diabetes Mellitus can also occur because the hormone insulin produced by the body cannot work properly (Mubarak, 20I3).

The limitation in this study is that some outpatients who were delivered were not delivered by their previous family, so the family empowerment exposure must be done again.

\section{CONCLUSION}

Based on the results of research and discussion conducted in Banjarmasin, South Kalimantan Province in 2020, it can be concluded as follows. After being given motivation to the family after completing the questionnaire, there was an average difference between the second variable before and after the family empowerment intervention with $p$ value $=0.00(p<0.05)$. The results show there is the influence of family empowerment with the self-efficacy of patients with diabetes mellitus in Banjarmasin.

A research limitation is that the family of patients who accompany patients often change and have not been exposed to family empowerment when accompanying outpatients, meaning researchers have to meet and relate family empowerment.

\section{Acknowledgement}

Thank you to everyone involved in this research, especially the hospital in Banjarmasin. Particularly to DIKTI for granting a PDP (Beginner Lecturer) grant funding so this research can be carried out. 


\section{Conflict of Interest}

This research is a research sourced from DIKTI funding; this research is a mandatory output target that must be achieved by researchers so that researchers must publish their research results in journals. The results of this study can be used by any party who has an interest in this research.

\section{REFERENCES}

Adman, \& Monica. (2017). Peran Efikasi Diri Dan Motivasi Belajar Mahasiswa Menengah Kejuruan.

Amelia, M., \& Nurchayati, S. (20|4). Analisis Faktor-Faktor Yang Mempengaruhi Keluarga Untuk Memberikan Dukungan Kepada Klien Diabetes Mellitus Dalam Menjalani Diet.

Andra, \& Putri, T. (20|3). KMB I. Keperawatan Medikal Bedah (Keperawatan Dewasa. Teori dan Contoh Askep. (I). Nuha Medika.

Ardian, I. (20I3). Pemberdayaan Keluarga ( Family Empowerment ) Meningkatkan Koping Keluarga Diabetes Militus Tipe-2. Jurnal Ilmu Keperawatan, I(2), $141 \square 149$.

Astuti, \& Neneng. (20/4). Efikasi Diri Dan Manajemen Diri Pada Pasien Dengan Diabetes Tipe-2. Jurnal Photon.

Fitriana, Rehmatul, \& Rahmawati, S. (20I6). Cara Ampuh Tumpas Diabetes. Medika.

Hernilawati. (2013). Konsep dan Proses Keperawatan Keluarga. Pustaka AsSALA.

Hidayat, F., Hamid, A. Y. S., \& Mustikasari. (20I4). Penyandang Diabetes Mellitus Sebagai Anggota. 175 $\square$ I83.

Hutama, R. (2016). Pengaruh Antara Efikasi Diri Dan Religiusitas Terhadap Kebahagiaan Penderita Diabetes Tipe-2.
Indriyani, P., \& Supriyanto, H. (2007). Pengaruh Latihan Fisik; Senam Aerobik Terhadap Penurunan Kadar Gula Darah Pada Penderita Dm Tipe 2 Di Wilayah Puskesmas Bukateja Purbalingga.

Muhibuddin, N., Sugiarto, \& Wujoso, H. (2016). Hubungan Pengetahuan dan Sikap Keluarga Dengan Terkendalinya Kadar Gula Pada Pasien Diabetes Mellitus Tipe-2.

Negara, C. K. (20|8). The Effect of Discharge Planning on Treatment Adherence among The Elderly with Hypertension in Banjarmasin, South Kalimantan. In 4th International Conference on Public Health 2018 (pp. 237-237). Sebelas Maret University.

Negara, C. K., Basid, A., Erliani, S., \& Turahman, I. (2019). The Relationship Between Discharge Planning and The Quality of Life of Patients with Diabetic Ulcer. Indonesian Nursing Journal Of Education And Clinic (INJEC), 4(I), 20-24

Negara, C. (2017). Post Amputation Response And Coping Of Diabetes Mellitus Patient In Ulin General Hospital Banjarmasin. Jurnal IImu Keperawatan, 5(2), II4 $\square$ I 29.

Patria. (20।8). Dahsyat-nya Hamil Sehat \& Norma. Ide Segar.

Purwanti. (20|4). Hubungan Motivasi Dengan Efikasi Diri Pasien DM Tipe 2 Dalam Melakukan Perawatan Kaki di Wilayah Kerja Puskesmas Ponorogo Utara.

Santoso, \& Singgih. (2010). Statistic Multivariat. Elex Media Komputindo.

Susanti, M., \& Sulistyartini. (20I3). Dukungan Keluarga Meningkatkatkan Kepatuhan Diet Pasien Diabetes Mellitus Di Ruang Rawat Inap Rs. Baptis Kediri. 